\title{
Myelodysplastic Syndrome in Pakistan: Clinicohematological Characteristics, Cytogenetic Profile, and Risk Stratification
}

\author{
Pakistan'da Myelodisplastik Sendrom: Klinikohematolojik Özellikler, Sitogenetik Profil ve \\ Risk Stratifikasyonu
}

Rafia Mahmood, (D) Chaudry Altaf, (D) Parvez Ahmed, (D) Saleem Ahmed Khan, (D) Hamid Saeed Malik

Armed Forces Institute of Pathology, Department of Hematology, Rawalpindi, Pakistan

\section{Abstract}

Objective: Myelodysplastic syndrome (MDS) is a group of bone marrow diseases that not only have variable morphological presentation and heterogeneous clinical courses but also have a wide range of cytogenetic abnormalities. Clinicohematological parameters have a significant role in diagnosis and along with identification of cytogenetic abnormalities are important for prognostic scoring and risk stratification of patients to plan management and make treatment decisions. This study aimed to determine the clinicohematological characteristics, cytogenetic abnormalities, and risk stratification of newly diagnosed de novo MDS patients.

Materials and Methods: This cross-sectional study was conducted in the Department of Hematology, Armed Forces Institute of Pathology, Rawalpindi, from January 2013 to January 2017. Patients were diagnosed on the basis of World Health Organization criteria for MDS, clinicohematological parameters were noted, and cytogenetic analysis was performed. Risk stratification was done using the Revised International Prognostic Scoring System.

Results: A total of 178 cases of MDS were analyzed, including 119 males (66.9\%) and 59 females (33.1\%). The median age was 58 years. The most common presenting feature was anemia in 162 (91\%) of the patients. MDS with multilineage dysplasia was the most common diagnosis, seen in $103(57.9 \%)$ patients. A normal karyotype was seen in 95 (53.4\%), while 83 (46.6\%) showed clonal karyotypic abnormalities at diagnosis. Of these, the common abnormalities found were trisomy 8 , complex karyotype, and del $5 q$. Risk stratification revealed low-risk disease in $73(41 \%)$ patients.

Conclusion: Cytogenetic analysis showed the normal karyotype to be the most common while risk stratification revealed a predominance of low-risk disease at the time of presentation.

Keywords: Myelodysplastic syndrome, Cytogenetics, Revised International Prognostic Scoring System

\section{Öz}

Amaç: Myelodisplastik sendrom (MDS) sadece değişken morfolojik prezentasyona ve heterojen klinik seyre değil geniş sitogenetik anormallikler yelpazesine de sahip olan bir grup kemik iliği hastalığıdır. Klinikohematolojik parametreler tanıda önemli role sahiptir ve sitogenetik anormalliklerin tanımlanması ile birlikte prognostik skorlamada ve yönetimi planlamak ve tedavi kararlarını vermek için risk stratifikasyonunda önemlidir. Bu çalışma, yeni tanı de novo MDS hastalarında klinikohematolojik özellikler, sitogenetik anormallikler ve risk stratifikasyonunu belirlemeyi amaçlamıştır.

Gereç ve Yöntemler: Bu kesitsel çalışma Rawalpindi Silahlı Kuvvetler Patoloji Enstitüsü Hematoloji Departmanı'nda Ocak 2013'ten Ocak 2017 tarihine kadar sürdürülmüştür. Hastalar Dünya Sağlık Örgütü MDS kriterlerine göre teşhis edildi, klinikohematolojik parametreler not edildi ve sitogenetik analiz yapıldı. Risk stratifikasyonu Revize Uluslararası Prognostik Skorlama Sistemi kullanılarak yapıldı.

Bulgular: Toplam 178 MDS olgusu, 119 erkek $(\% 66,9)$ ve 59 kadın $(\% 33,1)$ analiz edildi. Medyan yaş 58 idi. Başvuruda en sık görülen belirti olguların 162'sinde (\%91) anemi idi. En sık tanı MDS çoklu seride displazi olup $103(\% 57,9)$ hastada görüldü. Teşhiste normal karyotip $95(\% 53,4)$ olguda görülürken $83(\% 46,6)$ olgu klonal karyotipik anormallikler gösterdi. Bunlar arasında, en sık görülenler trizomi sekiz, kompleks karyotip ve del5q idi. Risk stratifikasyonu 73 (\%41) hastada düşük-risk hastalık ortaya koydu.

Sonuç: Sitogenetik analiz en sık normal karyotipi gösterirken risk stratifikasyonu tanı sırasında düşük-risk hastalığın çoğunlukta olduğunu ortaya koymuştur.

Anahtar Sözcükler: Myelodisplastik sendrom, Sitogenetik, Revize Uluslararası Prognostik Skorlama Sistemi 


\section{Introduction}

Myelodysplastic syndrome (MDS) is a heterogeneous group of clonal stem cell disorders characterized by peripheral blood cytopenias, dysplasia, and ineffective hematopoiesis [1]. Patients have a variable clinical course and there is an increased risk of myeloid leukemic transformation [2]. It is a disease of the elderly; its incidence increases with age. It is slightly more common in males with a male:female ratio of 1.4:1 [3]. While a few patients may be detected incidentally when a routine blood count reveals unexpected cytopenia, most present with symptoms and signs of bone marrow failure. Notable findings include fatigue due to anemia, infections, and bleeding [4].

Morphologic dysplasia is the hallmark of the disease [5]. Dysplasia may be seen in any or all of the three lineages [6]. The World Health Organization (WHO) has classified the myelodysplastic syndromes based on the number of cytopenias, dysplasia in a single lineage or in multiple lineages, cytogenetics, the number of blast cells, and the presence or absence of ring sideroblasts [5].

In addition to morphologic heterogeneity, MDS cases show profound heterogeneity in their genetic presentation [7]. More than half the patients show clonal chromosomal abnormalities with a predominance of unbalanced abnormalities [8]. Cytogenetic analysis not only has an important role in diagnosis where certain chromosomal abnormalities are considered presumptive evidence of MDS, but also has important prognostic implications. These cytogenetic abnormalities can be detected by conventional metaphase karyotyping. However, fluorescent in situ hybridization (FISH) has been seen to have a much higher sensitivity for detection of del $5 q$ [9]. These cytogenetic findings serve as a basis for the characterization of cytogenetic subgroups [10].

Over time, a better understanding of the biology of disease has shown cytogenetics to be an important prognostic parameter [11]. The Revised International Prognostic Scoring System (R-IPSS) refines risk group definitions, aiming for better prediction of individual prognosis. The parameters included are the degree of cytopenias, the number of blast cells, and the cytogenetic subgroup [12]. The prognostication of patients based on individualized risk assessment not only predicts disease progression but also provides an important tool in planning management and making treatment decisions [13].

Most studies regarding MDS are from Western populations. Disease biology, clinical presentations, and cytogenetic findings are different and distinctive for population groups and can show noticeable differences in geographic prevalence around the world. The present study was designed with an aim to see the clinicohematological features, cytogenetic profile, and risk stratification of the patients of Pakistan (an Asian population) as so far there is a lack of data on MDS in our region. This will help to determine treatment protocols and prognosis.

\section{Materials and Methods}

\section{Patients}

This study was a cross-sectional analysis conducted in the Department of Hematology of the Armed Forces Institute of Pathology, Rawalpindi, from January 2013 to January 2017. All patients were Pakistanis, of Asian origin, belonging to different ethnic groups including Punjabis, Pashtuns, Sindhis, Balochis, Kashmiris, and those from Gilgit-Baltistan. Patients were between the ages of 30 and 85 years. These patients were newly diagnosed with MDS and had no previous history of any treatment. Patients who had failed culture (did not yield at least 20 metaphases) in cytogenetic analysis were excluded from the study. All subjects were thoroughly informed about the study and written informed consent was obtained.

\section{Clinicohematological Parameters}

Detailed history was recorded and complete physical examination was done. Symptoms and signs were noted. Complete blood count, peripheral blood film, and bone marrow examination were done and patients were diagnosed as having MDS based on the WHO criteria.

\section{Cytogenetics and FISH}

Cytogenetic analysis was performed by using the conventional $\mathrm{G}$ banding technique. A bone marrow specimen of $3 \mathrm{~mL}$ was collected in sodium heparin. Metaphase chromosomes were banded using the conventional Giemsa trypsin banding technique and karyotyped according to the International System for Human Cytogenetic Nomenclature criteria. At least twenty metaphases were analyzed with the CytoVision semiautomated image analysis and capture system.

Interphase FISH studies were performed on blood or bone marrow specimens processed by standard methods for cultured samples. The MetaSystems XL $5 q 31 / 5 q 33$ probe $(10 \mu \mathrm{L})$ was applied to the target on the slide. A total of 500 nuclei were analyzed per probe set by using a fluorescent microscope with an orange green spectrum filter.

\section{Risk Stratification}

The patients were risk-stratified according to the R-IPSS.

\section{Statistical Analysis}

Collected data were entered and analyzed using SPSS 20 (IBM Corp., Armonk, NY, USA). Quantitative variables, i.e. age, hemoglobin ( $\mathrm{Hb})$, platelet count, and absolute neutrophil count (ANC), have been presented as mean \pm standard deviation. 
Qualitative variables, i.e. sex, cytogenetics, and risk category, have been presented as frequency and percentage.

\section{Ethical Approval}

This study was approved by the Ethical Review Committee of the Armed Forces Institute of Pathology, Rawalpindi. Informed written consent was received from the patients.

\section{Results}

A total of 178 patients were diagnosed as having de novo MDS. The median age of the patients was 58 years. Out of 178 patients, $119(66.9 \%)$ were male, while the remaining $59(33.1 \%)$ patients were female.

The most common presenting clinical feature was pallor, followed by symptoms of fatigue, recurrent infections, and bruising/bleeding; 118 (66\%) of the patients were transfusiondependent at the time of presentation. Mean $\mathrm{Hb}$ was $6.4 \mathrm{~g} / \mathrm{dL}$ and mean platelet count was $97 \times 10^{\circ} / \mathrm{L}$, while the mean ANC was $2.1 \times 10^{9} / \mathrm{L}$. Table 1 shows the clinicohematological parameters of our patients. We classified our patients according to the 2016 revised WHO classification: 103 (57.9\%) of the patients were in the MDS-MLD (MDS with multilineage dysplasia) category while $36(20.2 \%)$ cases were classified as MDS-SLD (MDS with single lineage dysplasia), $16(8.9 \%)$ as MDS-EB1 (MDS with excess blasts-1), 12 (6.7\%) as MDS-EB2 (MDS with excess blasts-2), $6(3.4 \%)$ as MDS with isolated del (5q), $3(1.7 \%)$ as MDS-RSSLD (MDS with ring sideroblasts with single lineage dysplasia), and $2(1.1 \%)$ as MDS-RS-MLD (MDS with ring sideroblasts with multilineage dysplasia).

A normal karyotype was seen in 95 (53.4\%) cases, while 83 (46.6\%) patients showed clonal karyotypic abnormalities at diagnosis (Figure 1 and 2). Of these, 56 (31.4\%) had single and 8

\section{Table 1. Clinicohematological parameters of the patients.}

\begin{tabular}{|l|l|l|l|}
\hline Parameters & $\mathbf{n = 1 7 8}$ & $\%$ \\
\hline $\mathrm{Hb}<10 \mathrm{~g} / \mathrm{dL}$ & 174 & 97.8 \\
\hline Platelets $<100 \times 10^{9} / \mathrm{L}$ & 99 & 55.6 \\
\hline ANC $<1.5 \times 10^{9} / \mathrm{L}$ & 69 & 38.8 \\
\hline \multirow{4}{*}{ Cytopenia } & Unicytopenia & 45 & 25.3 \\
\cline { 2 - 4 } & Bicytopenia & 69 & 38.8 \\
\cline { 2 - 4 } & Pancytopenia & 64 & 35.9 \\
\hline \multirow{3}{*}{ Dysplasia } & Single lineage & 49 & 27.5 \\
\cline { 2 - 4 } & Multilineage & 129 & 72.5 \\
\hline \multirow{3}{*}{ Blasts } & PB $<1 \%$, BM $<5 \%$ & 150 & 84.8 \\
\cline { 2 - 4 } & PB 2\%-4\%, BM 5\%-9\% & 16 & 8.9 \\
\cline { 2 - 4 } & PB 5\%-19\%, BM 10\%-19\% & 12 & 6.2 \\
\hline \multicolumn{2}{|l|}{ Ring sideroblasts $>15 \%$} & 5 & 2.7 \\
\hline \multirow{2}{*}{$\begin{array}{l}\text { Hb: Hemoglobin, ANC: absolute neutrophil count, PB: peripheral blood, BM: bone } \\
\text { marrow. }\end{array}$} & \multicolumn{2}{|l}{} \\
\hline
\end{tabular}

(4.5\%) had double cytogenetic abnormalities while 19 (10.7\%) had a complex karyotype. Of the cytogenetic abnormalities seen, the most commonly found was trisomy 8 in $23(12.9 \%)$ cases, followed by del $5 q$ in $13(7.3 \%)$, monosomy 7 in $10(5.6 \%)$, loss of $Y$ in $5(2.8 \%)$, del $11 q$ in $5(2.8 \%)$, del $20 q$ in $4(2.2 \%)$, del $7 q$ in $3(1.7 \%)$ and $\mathrm{i}(17 \mathrm{q})$ in $1(0.6 \%)$ patient. Other abnormalities, including translocations, hyperdiploidy, hypodiploidy, deletions, and monosomies, were seen in $8(4.5 \%)$ of the patients. del $5 q$ was detected in 8 patients based on conventional cytogenetics while in 5 patients it was missed by conventional cytogenetics and detected by FISH.

Each parameter was assessed and scored according to the R-IPSS. Based on the score, the patients were stratified into five distinct risk groups. In the very-low-risk group, there were $17(9.6 \%)$ patients, while there were $73(41 \%)$ patients in the low-risk group, $48(27.1 \%)$ patients in the intermediate-risk group, 24 (13.5\%) patients in the high-risk group, and 16 (9.1\%) patients in the very-high-risk group.

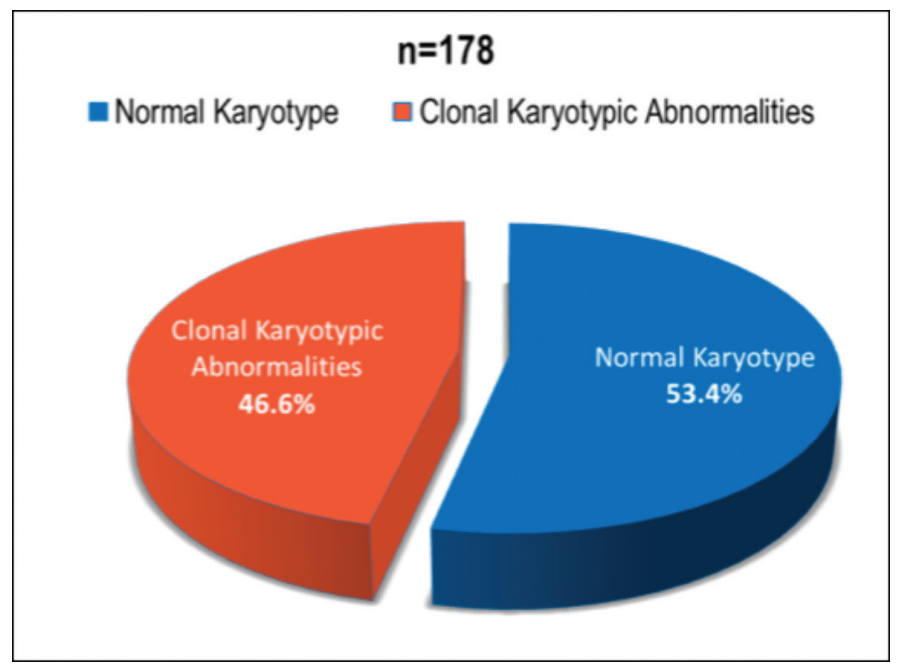

Figure 1. Cytogenetics of the patients.

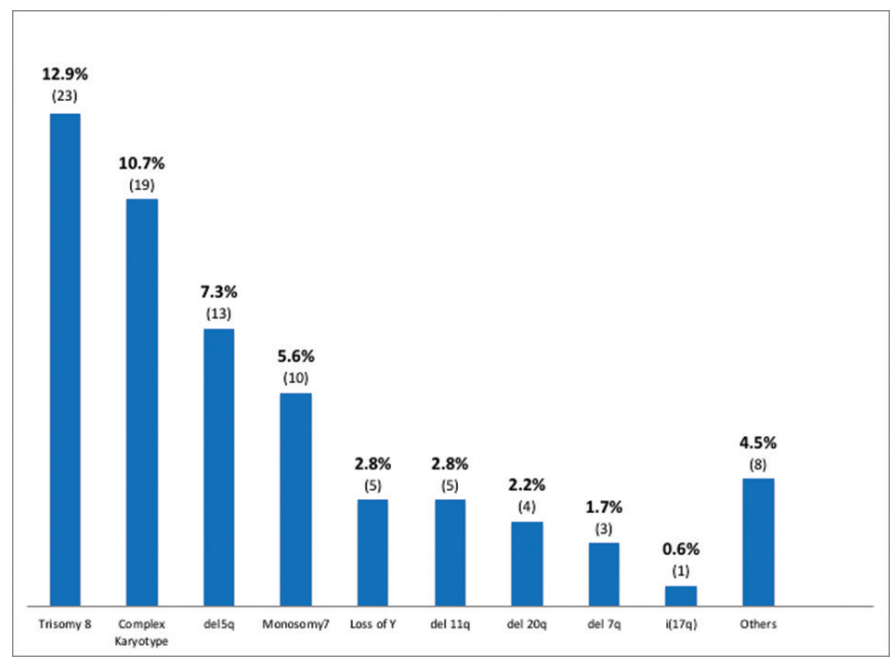

Figure 2. Common karyotypic abnormalities of the patients. 


\section{Discussion}

Myelodysplastic syndromes show not only clinical heterogeneity and genetic diversity but also a highly variable clinical course [14]. Over the last decade a better understanding of the biology of MDS has led to the identification of genetic molecular factors that have diagnostic value as well as roles in determining the disease course and prognosis [15]. Conventional cytogenetics of all newly diagnosed MDS patients is thus of paramount significance as it is an important component in risk-stratifying the patients [16]. FISH has a much higher sensitivity and has improved the detection of genomic aberrations in MDS, especially del $5 q[9]$.

To our knowledge, there are no comprehensive data available on the clinicohematological features, cytogenetic profiles, and risk stratification of MDS patients from our part of the country. The Armed Forces Institute of Pathology is a tertiary care institute and a referral center in the north of Pakistan. It caters to a large number of patients from all over the country from very different ethnic backgrounds. Our study aims to help clinicians in structuring treatment decisions in light of cytogenetically based risk stratification.

In our study, the median age of the patients was 58 years. Similar findings have been reported in local studies. However, a much higher age, 71 years, was reported by Greenberg et al. [11] in a Western population. There is a major difference in the age of presentation of our patients and the Western population. These differences may be attributable to racial and geographic differences and differences in disease biology in different populations. Among our patients, males were more common as compared to females (66.9\% vs. $33.1 \%)$. The male-to-female ratio was 2:1. Our observation coincides with the findings of Sultan and Irfan [17], who reported a sex ratio of 1.6:1. Deeg et al. [18] also reported a male predominance.

The most common presenting clinical findings of pallor followed by fatigue observed in our study are consistent with those reported by Narayanan [19] in the Indian population. Of our patients, $66 \%$ were transfusion-dependent at the time of presentation. A similar frequency of $58 \%$ was reported in the Italian population, while Greenberg et al. [11] reported 32\% of the patients to be transfusion-dependent based on data from eleven countries. Mean $\mathrm{Hb}$ was $6.4 \mathrm{~g} / \mathrm{dL}$. Chaubey et al. [20] demonstrated mean $\mathrm{Hb}$ of $6.8 \mathrm{~g} / \mathrm{dL}$, which is in accordance with our findings. In another study, Voso et al. [12] reported mean $\mathrm{Hb}$ of $9.9 \mathrm{~g} / \mathrm{dL}$ in Italian patients. There is a striking difference in presenting $\mathrm{Hb}$ levels and transfusion dependency in our population as compared to the Western populations studied by Greenberg et al. [11]. This may be due to the fact that Pakistan is a developing country and patients present late as they do not have early access to tertiary care medical facilities. However, these differences in presentation, with more than two-thirds of our patients being transfusion-dependent, may affect the overall treatment plan. These patients need further stratification by evaluation of their erythropoietin levels, which will guide further management. In patients with low erythropoietin levels (less than $200 \mathrm{IU} / \mathrm{L}$ ), early institution of erythropoietin therapy predicts the response. Erythropoietin therapy not only improves $\mathrm{Hb}$ levels but also enhances the quality of life without the risks associated with blood transfusions. Iron chelation will also be an

Table 2. Comparison of clinicohematological characteristics with national and international studies.

\begin{tabular}{|c|c|c|c|c|c|c|c|c|c|c|}
\hline \multicolumn{2}{|c|}{ Parameters } & $\begin{array}{l}\text { Our } \\
\text { study }\end{array}$ & $\begin{array}{l}\text { Rashid } \\
\text { et al. } \\
\text { [21] }\end{array}$ & $\begin{array}{l}\text { Sultan } \\
\text { and } \\
\text { Irfan } \\
{[17]}\end{array}$ & $\begin{array}{l}\text { Ehsan and } \\
\text { Aziz } \\
{[22]}\end{array}$ & $\begin{array}{l}\text { Chaubey } \\
\text { et al. } \\
\text { [20] }\end{array}$ & $\begin{array}{l}\text { Narayanan } \\
{[19]}\end{array}$ & $\begin{array}{l}\text { Avgerinou } \\
\text { et al. } \\
\text { [23] }\end{array}$ & $\begin{array}{l}\text { Voso } \\
\text { et al. } \\
{[12]}\end{array}$ & $\begin{array}{l}\text { Greenberg } \\
\text { et al. } \\
\text { [11] }\end{array}$ \\
\hline \multicolumn{2}{|c|}{ Median age (years) } & 58 & 60 & 64 & - & 42 & 67 & 74 & 71 & 71 \\
\hline \multicolumn{2}{|c|}{ M:F ratio } & $2: 1$ & $1.4: 1$ & $1.7: 1$ & $1.6: 1$ & - & 2.3:1 & $2.4: 1$ & $1.1: 1$ & $1.5: 1$ \\
\hline \multicolumn{2}{|c|}{ Fatigue (\%) } & 91 & - & 60 & 92.5 & - & 90 & 55 & - & - \\
\hline \multicolumn{2}{|c|}{ Fever/infection (\%) } & 25.3 & - & 33.3 & 55 & - & 31.7 & 15 & - & - \\
\hline \multicolumn{2}{|c|}{ Pallor (\%) } & 92 & - & 37.7 & - & - & 75 & - & - & - \\
\hline \multicolumn{2}{|c|}{ Mean $\mathrm{Hb}(\mathrm{g} / \mathrm{dL})$} & 6.4 & - & 7.7 & 6.5 & 6.8 & 5.5 & 9.5 & 9.9 & - \\
\hline \multicolumn{2}{|c|}{ Mean platelet $\left(\times 10^{9} / I\right)$} & 97 & - & 82.7 & 59.6 & 84.5 & - & 158 & 152 & - \\
\hline \multirow[t]{2}{*}{ Blasts } & BM 5-10\% & 8.9 & 18.3 & - & - & - & - & - & 23 & 19 \\
\hline & $\mathrm{BM}>10 \%$ & 6.2 & 12.7 & - & - & - & - & - & 9 & 16 \\
\hline \multicolumn{2}{|c|}{ Median LDH (IU/L) } & 381 & - & - & - & - & - & - & 317 & - \\
\hline
\end{tabular}




\begin{tabular}{|c|c|c|c|c|c|c|c|c|c|}
\hline Parameters & $\begin{array}{l}\text { Our } \\
\text { study }\end{array}$ & $\begin{array}{l}\text { Rashid et } \\
\text { al. [21] }\end{array}$ & $\begin{array}{l}\text { Chaubey et } \\
\text { al. [20] }\end{array}$ & $\begin{array}{l}\text { Narayanan } \\
\text { [19] }\end{array}$ & $\begin{array}{l}\text { Chen et } \\
\text { al. [25] }\end{array}$ & $\begin{array}{l}\text { Lee et } \\
\text { al. [24] }\end{array}$ & $\begin{array}{l}\text { Avgerinou et } \\
\text { al. [23] }\end{array}$ & $\begin{array}{l}\text { Voso et } \\
\text { al. [12] }\end{array}$ & $\begin{array}{l}\text { Haase et } \\
\text { al. [8] }\end{array}$ \\
\hline Abnormal karyotype & 46.6 & 42.3 & 47.5 & 34.6 & 37.1 & 44 & 38.4 & 39 & 51 \\
\hline Complex karyotype & 10.7 & 15.5 & - & - & - & 15.1 & 7.6 & 6 & - \\
\hline Monosomy 7 & 5.6 & - & 15 & - & 1.6 & 1.7 & 3 & 2 & 8 \\
\hline Loss of $Y$ & 2.8 & 2.8 & - & 5.8 & - & 2.5 & 5.8 & - & 2.8 \\
\hline del $11 q$ & 2.8 & 1.4 & - & - & - & - & - & - & 1.1 \\
\hline del 20q & 2.2 & 1.4 & - & - & 5.4 & - & 2.2 & 5 & 3.6 \\
\hline
\end{tabular}

Table 4. Comparison of cytogenetic subgroups and risk stratification.

\begin{tabular}{|c|c|c|c|c|}
\hline & $\begin{array}{l}\text { AFIP } \\
n=178 \\
\%\end{array}$ & $\begin{array}{l}\text { Narayanan [19] } \\
n=52 \\
\%\end{array}$ & $\begin{array}{l}\text { Greenberg et al. [11] } \\
n=7012 \\
\%\end{array}$ & $\begin{array}{l}\text { Voso et al. [12] } \\
\mathbf{n}=380 \\
\%\end{array}$ \\
\hline \multicolumn{5}{|c|}{ Cytogenetic subgroup } \\
\hline Very good & 5.6 & 5.8 & 4 & 3 \\
\hline Good & 62.9 & 86.5 & 72 & 77 \\
\hline Very poor & 3.4 & - & 7 & 3 \\
\hline \multicolumn{5}{|c|}{ Risk stratification } \\
\hline Very low & 9.6 & 9.6 & 19 & 38 \\
\hline Low & 41.0 & 34.6 & 38 & 33 \\
\hline
\end{tabular}

important consideration in patients who have received multiple transfusions.

In our study, the mean platelet count was $97 \times 10^{9} / \mathrm{L}$, while a mean platelet count of $100.5 \times 10^{9} / \mathrm{L}$ was reported in Indians [20] and $152 \times 10^{9} / \mathrm{L}$ [12] in the Italian population. The mean ANC in our study population was $(2.1 \pm 1.8) \times 10^{9} / \mathrm{L}$, which correlates with the median ANC of $1.9 \times 10^{9} / \mathrm{L}$ reported by Voso et al. [12]. The clinicohematological characteristics of our study population are compared with those of national and international studies in Table 2.

On cytogenetic analysis, a normal karyotype was seen in 95 patients (53.4\%), while $83(46.6 \%)$ patients showed clonal karyotypic abnormalities at diagnosis. Chromosomal abnormalities were detected in $34.6 \%$ of cases by Narayanan [19], 39\% by Voso et al. [12], 42.3\% by Rashid et al. [21], 47.5\% by Chaubey et al. [20], and $48 \%$ by Cao et al. [9]. A complex karyotype, which carries poor overall survival, was seen in 10.7\% of our patients, while Rashid et al. [21] reported a frequency of 15.5\%.

Table 3 shows a comparison of the cytogenetic profile with national and international data. In our study, the most common cytogenetic abnormality was trisomy 8 in 12.9\% followed by del $5 q$ in $7.3 \%$ and monosomy 7 in $5.6 \%$ of the patients. Rashid et al. [21] reported trisomy 8 to be the most common cytogenetic abnormality with a frequency of 9.9\%. However, they reported a much lower frequency of del $5 q$ in $2.8 \%$ of the patients. This difference may be due to the difference in the cytogenetic methodology adopted, as we used FISH for detection of del $5 q$ in addition to conventional cytogenetics, as FISH has higher sensitivity. Chaubey et al. [20] reported monosomy 7 as the most frequent cytogenetic abnormality detected in 15\%, followed by del $5 q$ in 10\% and trisomy 8 in $7.5 \%$ of Indian patients. In the Italian population [12], the most common karyotypic abnormality reported is del $5 q$ in $10.5 \%$, while much lower frequencies of 5\% for trisomy 8 and 2\% for 
monosomy 7 have been reported. Identification of patients with del $5 q$ is particularly important as these patients are candidates for treatment with the immunomodulatory drug lenalidomide. Early initiation of treatment with lenalidomide not only leads to transfusion independence but also induces cytogenetic remission in this subgroup of patients.

The R-IPSS score is particularly useful in clinical decision-making and selection of appropriate treatment options while at the same time providing prognostic information and predicting outcome in response to disease-modifying therapies. Upon risk stratification by the R-IPSS, as shown in Table 4, most of our patients (41\%) were in the low-risk category, followed by $27.1 \%$ of the patients in the intermediate-risk category. These findings are in accordance with the findings of Greenberg et al. [11], who reported 38\% of their patients in the low-risk followed by $20 \%$ in the intermediaterisk and 19\% in the very-low-risk category. However, in an Italian study, Voso et al. [12] reported 38\% in the very-low-risk category, followed by $33 \%$ in the low-risk and $18 \%$ in the intermediate-risk category. Those patients in the high-risk and very-high-risk groups need stringent regular monitoring as they have poor prognosis and are potentially more likely to have disease progression and transformation into acute myeloid leukemia.

\section{Conclusion}

Cytogenetic analysis showed the normal karyotype to be the most common while among the cytogenetic abnormalities detected trisomy 8 was the most common. Risk stratification revealed a predominance of low-risk disease at the time of presentation. The results of our study are in accordance with other local studies with a few differences, which may be due to differences in the method of detection of chromosomal abnormalities. However, there are differences with studies in other parts of the world. These differences may be attributable to geographical and ethnic differences in disease biology and genetics. As MDS has a heterogeneous clinical course, genetic characterization of all newly diagnosed MDS patients is important not only for diagnosis but also for risk stratification so that individualized treatment can be instituted to improve survival and for predicting outcome.

\section{Acknowledgment}

We are grateful for the technical support provided by Parvez Iqbal.

\section{Ethics}

Ethics Committee Approval: Research Ethics and Academics Department, Armed Forces Institute of Pathology, Rawalpindi, Pakistan.

Informed Consent: Informed written consent was received from the patients.

\section{Authorship Contributions}

Surgical and Medical Practices: R.M., C.A.; Concept: R.M.; Design: R.M., H.S.M.; Data Collection or Processing: R.M.; Analysis or Interpretation: R.M.; Literature Search: R.M., C.A. P.A., S.A.K.; Writing: R.M., C.A.

Conflict of Interest: The authors of this paper have no conflicts of interest, including specific financial interests, relationships, and/or affiliations relevant to the subject matter or materials included.

\section{References}

1. de Swart L, Smith A, Johnston TW, Haase D, Droste J, Fenaux P, Symeonidis $A$, Sanz G, Hellström-Lindberg E, Cermák J, Germing U, Stauder R, Georgescu 0, MacKenzie M, Malcovati L, Holm MS, Almeida AM, Madry K, Slama B, Guerci-Bresler A, Sanhes L, Beyne-Rauzy O, Luño E, Bowen D, de Witte T. Validation of the revised international prognostic scoring system (IPSS-R) in patients with lower-risk myelodysplastic syndromes: a report from the prospective European LeukaemiaNet MDS (EUMDS) registry. Br J Haematol 2015;170:372-383.

2. Fenaux P. Myelodysplastic syndromes: from pathogenesis and prognosis to treatment. Semin Hematol 2004;41:6-12.

3. Ma X. Epidemiology of myelodysplastic syndromes. Am J Med 2012;125(7 Suppl):2-5.

4. Chatterjee T, Dixit A, Mohapatra M, Tyagi S, Gupta PK, Mishra P, Bhattacharya M, Karan AS, Pati HP, Saxena R, Choudhry VP. Clinical, haematological and histomorphological profile of adult myelodysplastic syndrome. Study of 96 cases in a single institute. Eur J Haematol 2004;73:93-97.

5. Arber DA, Orazi A, Hasserjian R, Thiele J, Borowitz MJ, Le Beau MM, Bloomfield CD, Cazzola M, Vardiman JW. The 2016 revision to the World Health Organization classification of myeloid neoplasms and acute leukemia. Blood 2016;127:2391-2405.

6. Brunning RD, Orazi A, Germing U, Le Beau MM, Porwit A, Baumann I, Vardiman JW, Hellstrom-Lindberg E. Myelodysplastic syndromes. In: Swerdlow SH, Campo E, Harris NL, Jaffe ES, Pileri SA, Stein H, Thiele J, Vardiman JW, (eds). WHO Classification of Tumours of Haemopoietic and Lymphoid Tissues. 4th ed. Lyon, IARC Press, 2008.

7. Haase D. Cytogenetic features in myelodysplastic syndromes. Ann Hematol 2008;87:515-526.

8. Haase $D$, Germing $U$, Schanz J, Pfeilstöcker $M$, Nösslinger T, Hildebrandt $B$, Kundgen $A$, Lübbert $M$, Kunzmann $R$, Giagounidis $A A$, Aul $C$, Trümper L, Krieger O, Stauder R, Müller TH, Wimazal F, Valent P, Fonatsch C, Steidl C. New insights into the prognostic impact of the karyotype in MDS and correlation with subtypes: evidence from a core dataset of 2124 patients. Blood 2007;110:4385-4395.

9. Cao $P$, Li Y, Li X, Zhang G, Chen F. Detecting chromosomal aberrations in myelodysplastic syndrome with fluorescence in situ hybridization and conventional cytogenetic analysis. Zhong Nan Da Xue Xue Bao Yi Xue Ban 2014;39:605-611.

10. Jonas BA, Greenberg PL. MDS prognostic scoring systems-past, present and future. Best Prac Res Clin Haematol 2015;28:3-13.

11. Greenberg PL, Tuechler $H$, Schanz J, Sanz G, Garcia-Manero G, Solé $F$, Bennett JM, Bowen $D$, Fenaux $P$, Dreyfus $F$, Kantarjian $H$, Kuendgen $A$, Levis A, Malcovati L, Cazzola M, Cermak J, Fonatsch C, Le Beau MM, Slovak ML, Krieger O, Luebbert M, Maciejewski J, Magalhaes SM, Miyazaki Y, Pfeilstöcker $M$, Sekeres $M$, Sperr WR, Stauder $R$, Tauro $S$, Valent $P$, Vallespi $T$, van de Loosdrecht AA, Germing U, Haase D. Revised International Prognostic Scoring System for myelodysplastic syndromes. Blood 2012;120:2454-2465.

12. Voso MT, Fenu $S$, Latagliata $R$, Buccisano F, Piciocchi A, Aloe-Spiriti MA, Breccia M, Criscuolo M, Andriani A, Mancini S, Niscola P, Naso V, Nobile 
C, Piccioni AL, D'Andrea M, D'Addosio A, Leone G, Venditti A. Revised International Prognostic Scoring System (IPSS) predicts survival and leukaemic evolution of MDS significantly better than the IPSS and WHO prognostic scoring system: validation by the Gruppo Romano Mielodisplasie Italian Regional Database. J Clin Oncol 2013;31:2671-2677.

13. Tefferi A, Vardiman JW. Myelodysplastic syndromes. N Engl J Med 2009;361:1872-1885.

14. Orazi A, Czader MB. Myelodysplastic syndromes. Am J Clin Pathol 2009;132:290-305.

15. Steensma DP, Bennett JM. The myelodysplastic syndromes: diagnosis and treatment. Mayo Clin Proc 2006;81:104-130.

16. Look AT. Molecular pathogenesis of MDS. Hematology Am Soc Hematol Educ Program 2005:156-160.

17. Sultan S, Irfan SM. Adult primary myelodysplastic syndrome: experience from a tertiary care center in Pakistan. Asian Pac J Cancer Prev 2016:17:1535-1537.

18. Deeg HJ, Scott BL, Fang M, Shulman HM, Gyurkocza B, Myerson D, Pagel JM, Platzbecker U, Ramakrishnan A, Radich JP, Sandmaier BM, Sorror M, Stirewalt DL, Wilson WA, Storb R, Appelbaum FR, Gooley T. Five-group cytogenetic risk classification, monosomal karyotype, and outcome after hematopoietic cell transplantation for MDS or acute leukemia evolving from MDS. Blood 2012;120:1398-1408.
19. Narayanan S. Clinical, hematological, and cytogenetic profile of adult myelodysplastic syndrome in a tertiary care center. J Blood Med 2017;8:21-27.

20. Chaubey R, Sazawal S, Dada R, Mahapatra M, Saxena R. Cytogenetic profile of Indian patients with de novo myelodysplastic syndromes. Indian J Med Res 2011;134:452-457.

21. Rashid A, Khurshid M, Shaikh U, Adil S. Chromosomal abnormalities in primary myelodysplastic syndrome. J Coll Physicians Surg Pak 2014;24:632-635.

22. Ehsan A, Aziz M. Clinico-haematological characteristics in Pakistani patients of primary MDS according to WHO classification. J Coll Physicians Surg Pak 2010;20:232-236.

23. Avgerinou $C$, Alamanos $Y$, Zikos $P$, Lampropoulou $P$, Melachrinou $M$, Labropoulou V, Tavernarakis I, Aktypi A, Kaiafas P, Raptis C, Kouraklis A, Karakantza $\mathrm{M}$, Symeonidis $\mathrm{A}$. The incidence of myelodysplastic syndromes in Western Greece is increasing. Ann Hematol 2013;92:877-887.

24. Lee JH, Lee JH, Shin YR, Lee JS, Kim WK, Chi HS, Park CJ, Seo EJ, Lee KH. Application of different prognostic scoring systems and comparison of FAB and WHO classification in Korean patients with MDS. Leukemia 2003; 17:305-313.

25. Chen B, Zhao WL, Jin J, Xue YQ, Cheng X, Chen XT, Cui J, Chen ZM, Cao 0 , Yang G, Yao Y, Xia HL, Tong JH, Li JM, Chen J, Xiong SM, Shen ZX, Waxman S, Chen Z, Chen SJ. Clinical and cytogenetic features of 508 Chinese patients with MDS and comparison with those in Western countries. Leukemia 2005; 19:767-775. 